\title{
Ultrastructural study on the morphological changes to male worms of Schistosoma mansoni after in vitro exposure to allicin
}

\author{
Estudo ultraestrutural das alterações morfológicas de vermes machos de Schistosoma mansoni \\ após exposição in vitro à alicina
}

\begin{abstract}
Caliandra Maria Bezerra Luna Lima ${ }^{1}$, Francisca Inês de Sousa Freitas ${ }^{2}$, Liana Clébia Soares Lima de Morais $^{1}$, Marília Gabriela dos Santos Cavalcanti ${ }^{1}$, Lânia Ferreira da Silva ${ }^{3}$, Rafael José Ribeiro Padilha ${ }^{4}$, Constância Gayoso Simões Barbosa ${ }^{5}$, Fábio André Brayner dos Santos ${ }^{4,5}$, Luiz Carlos Alves ${ }^{3,4,5}$ and Margareth de Fátima Formiga Melo Diniz ${ }^{2}$
\end{abstract}

\begin{abstract}
IIntroduction: Garlic has a wide range of actions, including antibacterial, antiviral, antifungal, antiprotozoal and anthelmintic actions. This antiparasitic activity has been attributed to allicin which is the main constituent of garlic. The present study aimed to investigate the in vitro activity of allicin on the tegument of adult Schistosoma mansoni worms using scanning electron microscopy. Methods: Swiss Webster mice were infected with S. mansoni cercariae (100 per mouse) and sacrificed 50 days later to acquire the adult worms. These worms were collected by perfusion and placed in RPMI medium 1,640 at $37^{\circ} \mathrm{C}$ before transferring to RPMI media containing 0 (control), 5, 10,15 and $20 \mathrm{mg} / \mathrm{mL}$ of allicin, where they were incubated for $2 \mathrm{~h}$. The worms were fixed in $2.5 \%$ glutaraldehyde solution, washed twice, post-fixed in osmium tetroxide, washed twice and then dehydrated with ascending grades of ethanol. The samples were air-dried, mounted on stubs, gold coated in an ion sputtering unit and viewed using a scanning electron microscope. Results: A concentration of $5 \mathrm{mg} / \mathrm{mL}$ caused wrinkling in the tegument; a concentration of $10 \mathrm{mg} /$ $\mathrm{mL}$ resulted in changes to tubercles and loss or modification of spines. With 15 and $20 \mathrm{mg} / \mathrm{mL}$ increasing damage to the tegument could be seen, such as vesicle formation and the presence of ulcers. Conclusions: These findings demonstrate the effect of allicin on adult S. mansoni worms and indicate that most of the changes occur at concentrations greater than that normally indicated for treatment.
\end{abstract}

Keywords: Garlic. Schistosoma mansoni. Scanning electron microscopy.

\section{RESUMO}

Introdução: $\mathrm{O}$ alho apresenta uma ampla gama de ações, incluindo antibacteriana, antiviral, antifúngico, antiprotozoário e anti-helmíntico. Esta atividade antiparasitária tem sido atribuída à alicina, que é o principal constituinte do alho. O presente estudo teve como objetivo investigar a ação in vitro da alicina no tegumento de vermes adultos de Schistosoma mansoni utilizando a microscopia eletrônica de varredura. Métodos. Camundongos Swiss Webster foram infectados com cercárias de S. mansoni (100 por camundongo) e sacrificados 50 dias depois para aquisição de vermes adultos. Estes vermes foram coletados por perfusão e colocados em meio RPM 1.640 a $37^{\circ} \mathrm{C}$ antes de transferir para o meio RPMI contendo 0 (controle), 5, 10, 15 e 20mg/ $\mathrm{mL}$ de alicina, onde eles foram incubados por $2 \mathrm{~h}$. Os vermes foram fixados em uma solução de glutaraldeído a 2,5\%, lavados duas vezes, pós-fixados em tetróxido de ósmio, lavados duas vezes e então desidratados em séries crescentes de etanol. As amostras foram secadas, montadas em stubs, metalizadas em ouro e visualizadas utilizando o microscópio eletrônico de varredura. Resultados: A concentração de $5 \mathrm{mg} / \mathrm{mL}$ causou o enrugamento do tegumento; a concentração de $10 \mathrm{mg} / \mathrm{mL}$ resultou em alterações nos tubérculos e perda ou modificações nos espinhos. Com 15 e 20mg/ $\mathrm{mL}$ crescentes danos no tegumento pode ser visto, tais como formação de vesículas e presença de úlceras. Conclusões: Esses resultados demonstram os efeitos da alicina nos vermes adultos de $S$. mansoni e indicam que a maioria das alterações ocorrem numa concentração maior do que a normalmente indicada para o tratamento.

Palavras-chaves: Alho. Schistosoma mansoni. Microscopia eletrônica de varredura.

1. Departamento de Fisiologia e Patologia, Universidade Federal da Paraíba, João Pessoa, PB. 2. Departamento de Ciências Farmacêuticas, Universidade Federal da Paraíba, João Pessoa, PB. 3. Departamento de Biologia Celular, Universidade de Pernambuco, Recife, PE. 4. Laboratório de Microscopia Eletrônica, Laboratório de Imunopatologia Keizo Asami, Universidade Federal de Pernambuco, Recife, PE. 5. Departamento de Parasitologia, Centro de Pesquisa Aggeu Magalhães, Fundação Oswaldo Cruz, Recife, PE.

Address to: Dr. Luiz Carlos Alves. Depto Parasitologia/UFPE. Av. Professor Moraes Rego s/n, Cidade Universitária, 50670-420 Recife, PE, Brasil.

Phone: 5581 2101-2500

e-mail: lcalves@cpqam.fiocruz.br

Received in 13/08/2010

Accepted in $04 / 11 / 2010$

\section{INTRODUCTION}

Schistosoma species include parasites of medical and veterinary importance that are responsible for schistosomiasis $^{1,2}$. This is one of the most prevalent parasitic infections and it consitutes a major public health problem with significant economic impact ${ }^{3-5}$. Praziquantel is used to treat infections caused by Schistosoma $s s p^{6}$ and is the drug of choice for human and veterinary parasites ${ }^{7}$. The effectiveness of this drug is well documented, despite evidence suggesting that resistance to this drug exists ${ }^{8}$. To develop alternative therapies for treating schistosomiasis, studies have been conducted to evaluate the power of medicinal plants ${ }^{9}$.

Allium sativum (garlic) is a bulbous herbaceous plant belonging to the Liliaceae family. It has been used since the beginning of humanity for treating many different diseases ${ }^{10,11}$. Garlic has gained credit as a formidable prophylactic and therapeutic agent in many cultures over the centuries and attention has been drawn to its use within modern medicine ${ }^{12}$.

Garlic is also known as an antiparasitic agent and this activity has been attributed to allicin, the main constituent of garlic ${ }^{13}$. Although it is recommended for treating intestinal parasites in humans, few studies exist regarding the action of A. sativum on parasites ${ }^{14}$. Although some studies have indicated that garlic is effective as an antibilharzial drug ${ }^{15,16}$, evaluation of the action of A. sativum has only been rarely reported. Therefore, this study aimed to characterize the in vitro activity of garlic on the tegument of male worms of S. mansoni.

\section{METHODS}

\section{Obtaining adult Schistosoma mansoni worms}

Adult S. mansoni worms were obtained by perfusion of the hepatic portal system of Swiss Webster mice 45-50 days after they were subjected 
to infection. The worms of the BH strain (Belo Horizonte-Brazil) were expelled and collected in Petri plates containing RPMI 1640 culture medium at $37^{\circ} \mathrm{C}$.

\section{Determination of in vitro susceptibility of Schistosoma mansoni to allicin}

After removal of the definitive host, the adult $S$. mansoni worms were washed in RPMI 1640, and then transferred to $35 \mathrm{~mm}$ diameter sterile tissue culture plates containing $2 \mathrm{~mL}$ of culture medium. Each well received two worms, which were then incubated at $37^{\circ} \mathrm{C}$. After allowing a period for the worms to adapt to the culture medium, allicin was added at concentrations of $0,5,10,15$ and $20 \mathrm{mg} / \mathrm{mL}$. These doses were equivalent to the plasma concentrations in individuals who respectively ingest $0,1,2,3$ and 4 garlic capsules. Each concentration was assayed in triplicate. The parasites were incubated for two hours and monitored during this time to evaluate motility, changes to the tegument and mortality rate.

\section{Motility evaluation}

The motility of the worms in the control group and the groups exposed to medication, were studied over a two-hour period by means of bright field microscopy. According to the motility criterion, the worms were considered to be dead when no movement was observed after three minutes of observation under a stereoscopic microscope.

\section{Ultrastructural evaluation}

Ultrastructural analysis was performed on worms at different concentrations recovered through in vitro analysis.

\section{Scanning microscopy}

The samples were fixed (2.5\% glutaraldehyde and $4 \%$ paraformaldehyde in $0.1 \mathrm{M}$ sodium cacodylate buffer, $\mathrm{pH} 7.2$ ) for $12 \mathrm{~h}$ at room temperature, washed in the same buffer and post-fixed in $1 \%$ $\mathrm{OsO}_{4}$ in sodium cacodylate buffer $0.1 \mathrm{M}, \mathrm{pH} 7.2$, for one hour. After post-fixing, the material was washed in the same buffer, dehydrated in an increasing ethanol series and then maintained at the critical point. After assembling and metallization, the material was observed by means of scanning electron microscopy (JEOL - JSM 5600LV).

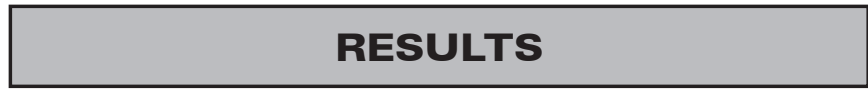

\section{Motility evaluation}

The worms were monitored at 30,60, 90 and $120 \mathrm{~min}$ and no mortality was observed at any of the concentrations studied. However, a change in motility between the groups was verified. At a concentration of $20 \mathrm{mg} / \mathrm{ml}$, the worms presented higher motility than at the other concentrations tested. While evaluating the adult worms, the females showed similar motility to the control group and the males presented lower motility.

\section{General morphology}

Using the routine procedure, the adult $S$. mansoni worms were analyzed by means of scanning electron microscopy (Figures 1A-F). The male worms exhibited two distinct portions: an anterior short, thin and cylindrical part containing the oral sucker (os) and the ventral sucker (vs). The ventral sucker was larger and more prominent than the oral sucker. The back was long and contained the gynecophoral canal (gc). The area between the oral and ventral suckers did not have any tubercles (tu), spines (sp) or sensory papillae. In the posterior region of the adult worms, there were tubercles with numerous spines randomly distributed throughout the body.

\section{Ultrastructural evaluation}

Treatment with allicin promoted damage to the structure of the tegument at all concentrations (Figures 2A-H). A concentration of $5 \mathrm{mg} / \mathrm{mL}$ caused the formation of projections on the tegument, while a concentration of $10 \mathrm{mg} / \mathrm{mL}$ resulted in damage to tubercles and the thorns became shorter and fewer. At 15 and $20 \mathrm{mg} / \mathrm{mL}$, increasing damage to the tubercles was observed, with the formation of vesicles and ulcers that exposed the musculature of the worm.

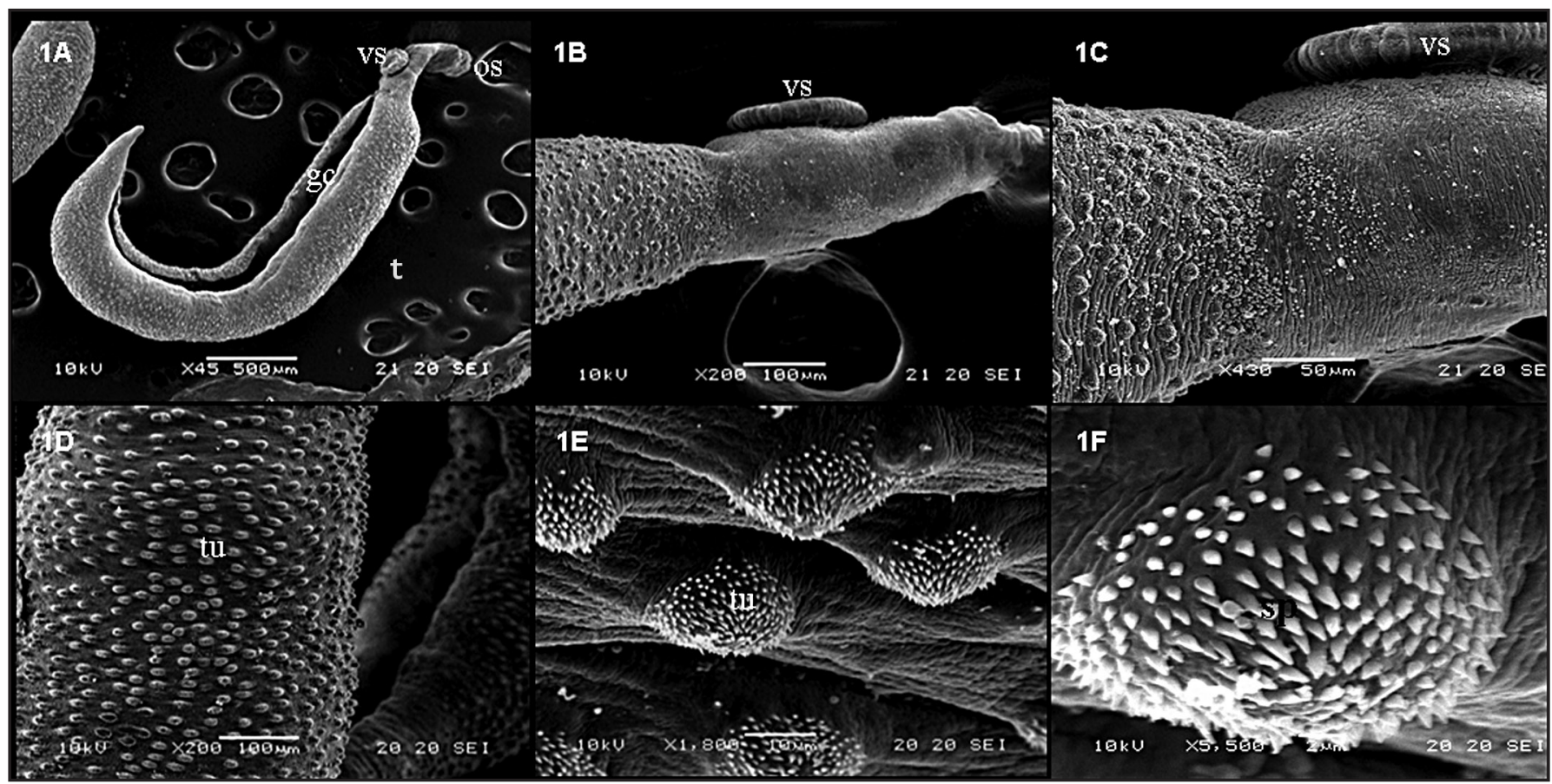

FIGURES 1 A-F: Worms of Schistosoma mansoni control processed to scan electron microscopy.

t: tegumet, tu: tubercles, sp: spines, os: oral suckers, vs: ventral suckers, gc: gynecophoral canal. 


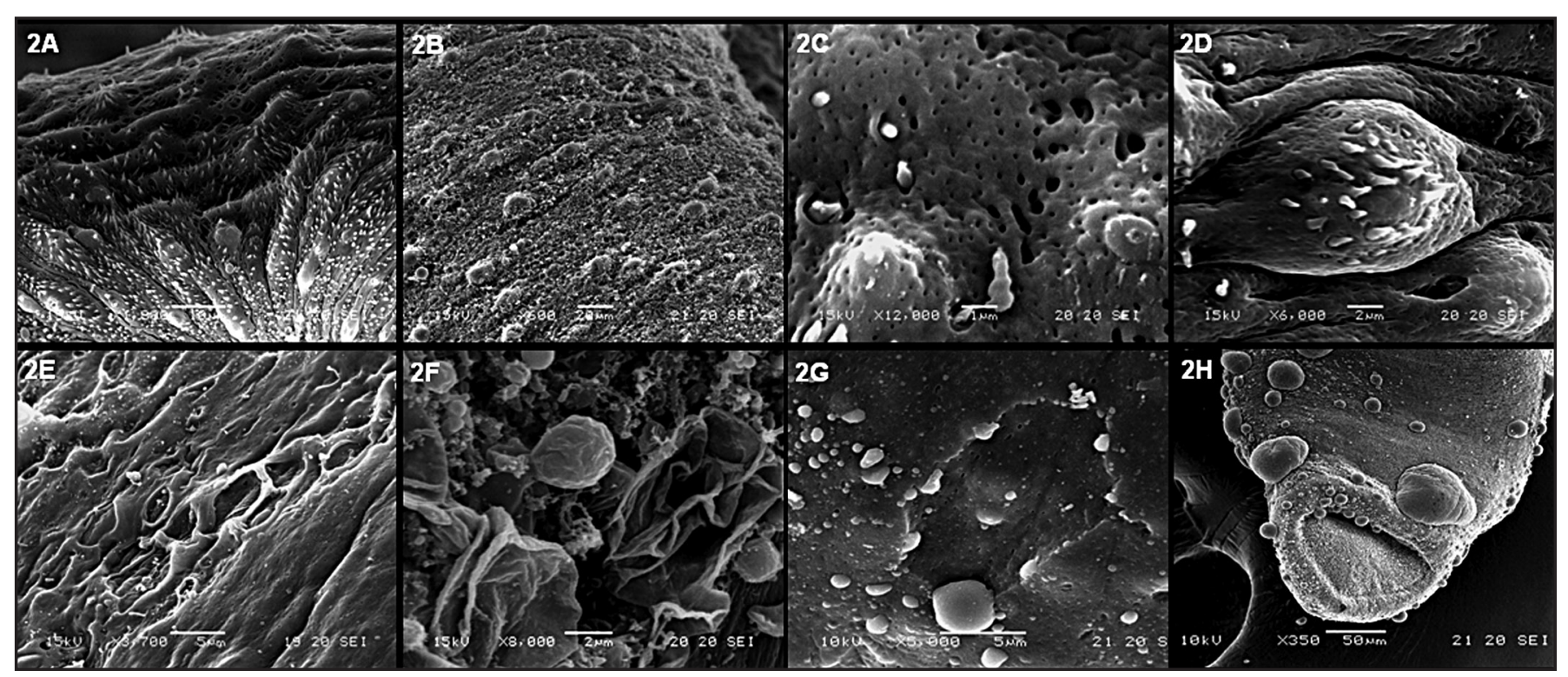

FIGURES 2 - A-H: Schistosoma mansoni worms after treatment with 5, 10, 15 and $20 \mathrm{mg} / \mathrm{mL}$ of allicin processed for scanning electron microscopy.

A-B: $5 \mathrm{mg} / \mathrm{ml}$ of allicin, observe wrinkling in the tegument, this observation is common in all concentrations.

C-D: $10 \mathrm{mg} / \mathrm{ml}$ of allicin, drilling tegument with tubercle deformation and loss of the spines.

E-F: $15 \mathrm{mg} / \mathrm{ml}$ of allicin, observe the ulceration in the tegument ( $2 \mathrm{E})$ and tegumental projections that can rupture and expose the tissue below it (2F).

G-H: $20 \mathrm{mg} / \mathrm{ml}$ of allicin, at this concentration, greater damage to the tegument is observed, with the formation of vesicles.

\section{DIscussION}

Schistosomiasis is treated through administration of two drugs that show good efficacy and low toxicity: oxamniquine and praziquantel ${ }^{17}$. Of these, praziquantel is the drug that is most often used. However, in recent years, S. mansoni has exhibited drug tolerance or resistance. It is therefore important to investigate and develop new drugs for treating this disease. Since the available drugs that are currently used for treating schistosomiasis are far from ideal, many scientists have sought substances originating from plants as alternative treatments for this helminthiasis ${ }^{15,18}$.

The antiparasitic activity of garlic has been known since antiquity $^{13}$ and its antischistosomal action has been reported ${ }^{16,19,20}$. The present study aimed to investigate the antischistosomal activity levels of allicin by means of scanning electron microscopy. The investigations were based on analysis of ultrastructural changes, since such tests have been documented for the drugs currently used for treating schistosomiasis: oxamniquine $\mathrm{e}^{21-25}$ and praziquantel ${ }^{22,26-32}$.

Many functions and features of the tegument of S. mansoni have raised the importance of studying it. It is involved in functions that are important for the worm, such as nutrient absorption, and it presents proteins that are responsible for maintenance of the host immune response or damage repair. Moreover, the tegument is the interface between the parasite and the host environment. Therefore, this structure of the parasite is an important target for drug action ${ }^{33,34}$.

The present results demonstrated that treatment with garlic did not result in killing the S. mansoni worms; however, variations in the tegument between the groups treated with garlic were observed. Ultrastructural analysis in vitro on the adult $S$. mansoni worms revealed that the tegument was the principal target for allicin. Observations verified by means of scanning electron microscopy on S. japonicum, S. mansoni and $S$. haematobium at different stages of development, which were obtained from animals treated with Artemether, a new antischistosomal drug, revealed that its target of action was also the tegument ${ }^{34}$.
The ultrastructural evaluation was performed on male specimens for two reasons: females are not in frequent contact with the host microenvironment and studies in the literature have shown that softtissue alterations are more pronounced in males than in females ${ }^{9,18}$.

The main changes in the worms' tegument induced by allicin at different concentrations were characterized by: the formation of projections at a concentration of $5 \mathrm{mg} / \mathrm{mL}$; changes to the tubercles and reduction and modification of the thorns at a concentration of $10 \mathrm{mg} / \mathrm{mL}$; and blistering and the presence of ulcers at concentrations of 15 and $20 \mathrm{mg} / \mathrm{mL}$. These data corroborate the findings of Nahed et al, in which they investigated the characteristics of the tegument of adult worms obtained from mice infected with cercariae of S. mansoni and subjected to treatment with garlic juice at a dose of $50 \mathrm{mg} / \mathrm{kg}$. They found a variety of structural changes to the tegument of the worms, including destruction of the tubercles, edema and ulcers. In addition, there were changes to the numbers and volume of thorns and modification of tubercles.

Ulcer formation was observed in the worms of the present study at concentrations of 15 and $20 \mathrm{mg} / \mathrm{mL}$. Similar lesions in the tegument were also observed by Mostafa and Soliman ${ }^{18}$, in investigations involving antischistosomal agents. Ulcers in the cuticle of the worm foster greater exposure of antigens on the tegument of the worm, leaving them more vulnerable to the host immune system. In such situations, the worm is recognized as non-self and is destroyed by the parasitized body ${ }^{35-37}$. This demonstrates the relevance of the results obtained here and justifies further studies in vivo, since praziquantel, the drug of choice for treating schistosomiasis, presents an important mechanism of action of many changes to the tegument of the worm ${ }^{38,39}$.

Analysis using scanning electron microscopy on adult S. mansoni worms treated with praziquantel showed that at a concentration of $0.8 \mathrm{mg} / \mathrm{mL}$, the dorsolateral tegument was found to be twisted, with shriveled tubercles and spines apparently deteriorated and numerically reduced in the gynecophoral channel. At a concentration 
of $6.3 \mathrm{mg} / \mathrm{mL}$, the dorsolateral region showed tissue loss and exposure of subcutaneous tissue, and the tubercles also showed loss of spines ${ }^{39}$. These findings demonstrate the same effect as garlic on adult worms of S. mansoni and indicate that most of the changes occur at concentrations greater than that normally indicated for the treatment.

\section{ACKNOWLEDGMENTS}

Federal University of Paraíba, Laboratory of Imunopatology Keizo Asami, Center of Reserch Aggeu Magalhães, and Laboratory of Pharmaceutical Technology.

\section{CONFLICT OF INTEREST}

The authors declare that there is no conflict of interest.

\section{REFERENCES}

1. Copeland CS, Brindley PJ, Heyers O, Michael SF, Johnston DA, Williams DL, et al. Boudicca, a retrovirus-like long terminal repeat retrotransposon from the genome of the human blood fluke Schistosoma mansoni.J Virol 2003; 77:6153-6166.

2. Moraes J, Silva MP, Ohlweiler FP, Kawano T. Schistosoma mansoni and other larval trematodes in Biomphalaria tenagophila (Planorbidae) from Guarulhos, São Paulo State, Brazil. Rev Inst Med Trop Sao Paulo 2009; 51:77-82.

3. Amaral RS, Tauil PL, Lima DD, Engels D. An analysis of the impact of the Schistosomiasis Control Programme in Brazil. Mem Inst Oswaldo Cruz 2006; 101:79-85.

4. Chitsulo L, Engels D, Montresor A, Savioli L. The global status of schistosomiasis and its control. Acta Trop 2000; 77:41-51.

5. Coura JR, Amaral RS. Epidemiological and control aspects of schistosomiasis in Brazilian endemic areas. Mem Inst Oswaldo Cruz 2004; 99:13-19.

6. Andrews P, Thomas H, Pohlke R, Seubert J. Praziquantel. Med Res Rev 1983; 3:147-200.

7. King $\mathrm{CH}$, Muchiri EM, Ouma JH. Evidence against rapid emergence of praziquantel resistance in Schistosoma haematobium, Kenya. Emerg Infect Dis 2000; 6:585-594

8. Ismail M, Botros S, Metwally A, William S, Farghally A, Tao LF, et al. Resistance to praziquantel: direct evidence from Schistosoma mansoni isolated from Egyptian villagers. Am J Trop Med Hyg 1999; 60:932-935.

9. Nahed HA, Riad HAT, Yomna IM. Effects of garlic on albino mice experimentally infected with Schistosoma mansoni: A parasitological and ultrastructural study. Trop Biomed 2009; 26:40-50.

10. Agarwal KC. Therapeutic actions of garlic constituents. Med Res Rev 1996; 16:111-124.

11. Jain AK, Vargas R, Gotzkowsky S, McMahon FG. Can garlic reduce levels of serum lipids? A controlled clinical study. Am J Med 1993; 94:632-635.

12. Banerjee SK, Maulik SK. Effect of garlic on cardiovascular disorders: a review. Nutr J 2002; 19:1-4.

13. Ankri S, Mirelman D. Antimicrobial properties of allicin from garlic. Microbes Infect 1999; 1:125-129.

14. Bianchin I, Catto JB. Alho desidratado (Allium sativum L.) no controle de nematódeos gastrintestinais em bovinos naturalmente infectados. Cienc. Rural 2004; 34:1267-1270.

15. El Shenawy NS, Soliman MF, Reyad SI. The effect of antioxidant properties of aqueous garlic extract and Nigella sativa as anti-schistosomiasis agents in mice. Rev Inst Med Trop Sao Paulo 2008; 50:29-36.

16. Riad NH, Fares NH, Mostafa OMS, Mahmoud YI. The effect of garlic on some parasitological and on hepatic tissue reactions in experimental schistosomiasis mansoni. J Appl Sci Res 2007; 3:949-960.

17. Lescano SZ, Chieffi PP, Canhassi RR, Boulos M, Amato Neto V. Antischistosomal activity of artemether in experimental Schistosomiasis mansoni. Rev Saude Publica 2004; 38:71-75.
18. Mostafa OM, Soliman MI. Experimental use of black-seed oil against Schistosoma mansoni in albino mice: II. Surface topography of adult worms. Egypt J Med Lab Sci 2002; 11:79-85.

19. Riad NHA, Fares NH, Mostafa OMS, Mahmoud YI. The effect of garlic on murine Schistosomiasis mansoni: a histological and ultrastructural study on the ileum. Res J Med Med Sci 2008;3:188-201.

20. Zakhary NI. Biochemical studies on the effect of garlic on liver and intestine of schistosomal mice.Egypt. J Bilharz 1994; 16:107-127.

21. Amin AM, Mikhail EG. Schistosoma mansoni: tegumental surface alterations following oxamniquine treatment of infected mice. J Egypt Soc Parasitol 1989; 19:815-826.

22. Fallon PG, Fookes RE, Wharton GA. Temporal differences in praziquanteland oxamniquine-induced tegumental damage to adult Schistosoma mansoni: implications for drug-antibody synergy. Parasitology 1996; 112:47-58.

23. Kohn A, López-Alvarez ML, Katz N. Transmission and scanning electron microscopical studies in the tegument of male Schistosoma mansoni after oxamniquine treatment. Ann Parasitol Hum Comp 1982; 57:285-291.

24. Magalhães Filho A, de Melo ME, Padovan PA, Padovan IP. Schistosoma mansoni: structural damage after treatment with oxamniquine. Mem Inst Oswaldo Cruz $1987 ; 82: 347-352$

25. Popiel I, Erasmus DA. Schistosoma mansoni: ultrastructure of adults from mice treated with oxamniquine. Exp Parasitol 1984; 58:254-262.

26. Becker B, Mehlhorn H, Andrews P, Thomas H, Eckert J. Light and electron microscopic studies on the effect of praziquantel on Schistosoma mansoni, Dicrocoelium dendriticum, and Fasciola hepatica (Trematoda) in vitro. Z Parasitenkd 1980; 63:113-128.

27. Liang YS, Coles GC, Dai JR, Zhu YC, Doenhoff MJ. Adult worm tegumental damage and egg-granulomas in praziquantel-resistant and -susceptible Schistosoma mansoni treated in vivo. J Helminthol 2002; 76:327-333.

28. Mehlhorn H, Becker B, Andrews P, Thomas H, Frenkel JK. In vivo and in vitro experiments on the effects of praziquantel on Schistosoma mansoni. A light and electron microscopic study. Arzneimittelforschung 1981; 31:544-554.

29. Mohamed AH, Ezz El-Din N, Fahmy ZH, El-Shennawy AM, Hassan E. Parasitological, hematological and ultrastructural study of the effect of COX-2 inhibitor, pyocyanin pigment and praziquantel, on Schistosoma mansoni infected mice. J Egypt Soc Parasitol 2006; 36:197-220.

30. Shaw MK, Erasmus DA. Schistosoma mansoni: dose-related tegumental surface changes after in vivo treatment with praziquantel. Z Parasitenkd 1983; 69:643-653.

31. Shaw MK, Erasmus DA. Schistosoma mansoni: structural damage and tegumental repair after in vivo treatment with praziquantel. Parasitology 1987; 94:243-254.

32. Shaw MK, Erasmus DA. Schistosoma mansoni: praziquantel-induced changes to the female reproductive system. Exp Parasitol 1988; 65:31-42.

33. Hoffmann KF, Strand M. Molecular identification of a Schistosoma mansoni tegumental protein with similarity to cytoplasmic dynein light chains. J Biol Chem 1996; 271:26117-26123.

34. Xiao S, Shen B, Utzinger J, Chollet J, Tanner M. Ultrastructural alterations in adult Schistosoma mansoni caused by artemether. Mem Inst Oswaldo Cruz 2002; 97:717-724.

35. Doenhoff MJ, Modha J, Lambertucci JR. Anti-schistosome chemotherapy enhanced by antibodies specific for a parasite esterase. Immunology $1988 ; 65: 507-510$.

36. Modha J, Lambertucci JR, Doenhoff MJ, McLaren DJ. Immune dependence of schistosomicidal chemotherapy: an ultrastructural study of Schistosoma mansoni adult worms exposed to praziquantel and immune serum in vivo. Parasite Immunol 1990; 12:321-334.

37. Doenhoff MJ, Modha J, Lambertucci JR, McLaren DJ. The immune dependence of chemotherapy. Parasitol Today 1991; 7:16-18.

38. Ribeiro F, Mello RT, Tavares CA, Kusel JR, Coelho PM. Synergistic action of praziquantel and host specific immune response against Schistosoma mansoni at different phases of infection. Rev Inst Med Trop São Paulo 2004; 46:231-233.

39. Burgo AMM, Cavalcanti MGS, Lima CMBL, Padilha RJR, Barbosa CCGS, Alves LC, et al. Ultrastructural evaluation of adult Worms of Schistosoma mansoni after in vitro treatment with praziquantel. In: XXII Congresso da Sociedade Brasileira de Microscopia e Microanálise 2009, Belo Horizonte. Microsc Acta 2009; 18. 